
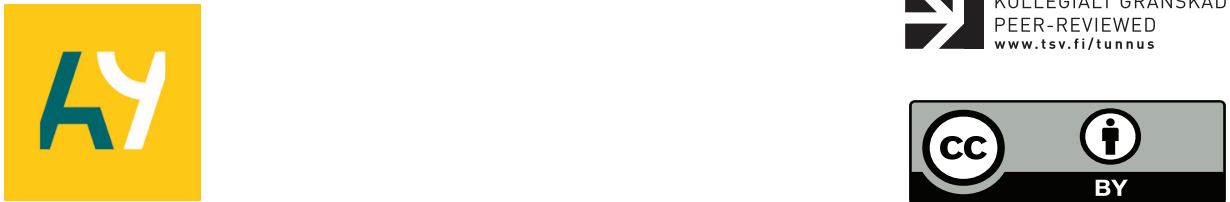

Kristiina Janhonen ${ }^{a}$, Malla Mattila ${ }^{b}$, Nina Mesirantac, Anna Kouhia ${ }^{d}$, Minna Autio ${ }^{e}$, Elina Närvänen ${ }^{f}$

\title{
Kohti kestäväå kuluttamista: materiaalitaju kuluttajien ja materiaalien aktiivisen suhteen hahmottajana
}

\section{Towards sustainable consumption: Material sense as an active relationship between consumers and materials}

The article outlines the concept of material sense as an active and situational relationship between consumers and materials. The aim is to create new understanding of consumers' relations with materials as part of sustainable consumption. On the conceptual level, material sense is built upon the discussions and critique of literacy. Through drawing theoretical influences from pragmatism and neo-materialism, the concept of material sense emphasises the momentary, relational, open-ended, and lively nature of interrelationships with materials. In addition, material sense builds an understanding of how consumers creatively learn and change their ways of interacting with materials. The concept of material sense introduces into sustainable consumption research more strongly than before the idea of active agencies of materials and a wide range of interfaces between material relationships in the daily life of consumers. In the article, we define material sense through four dimensions (situationality, temporality, liveliness, corporeality), in relation to which we outline four sustainability related empirical examples as a foundation for applied research in the future.

Keywords: material sense, sustainability, consumption, learning

\section{Johdanto}

Kestävän kehityksen perustavanlaatuinen lähtökohta on ajatus siitä, että meidän tulisi pystyä täyttämään tarpeemme niin, että elämä maapallolla olisi mahdollista myös tulevaisuudessa (WCED 1987). Tällä hetkellä tapamme käyttää luonnonvaroja sekä yksilökeskeiseen materiaalien ja energian kulutukseen nojaavat elämäntapamme eivät kuitenkaan täytä tätä vaatimusta, vaan vaarantavat tulevien sukupolvien mahdollisuudet tyydyttää perustarpeensa (mm. Pulkki ym. 2019). Pyrkimykset edistää materiaalien kestävää käyttöä esimerkiksi

\footnotetext{
a Kasvatustieteellinen tiedekunta, Helsingin yliopisto, kristiina.janhonen@helsinki.fi

b Johtamisen ja talouden tiedekunta, Tampereen yliopisto, malla.mattila@tuni.fi

c Johtamisen ja talouden tiedekunta, Tampereen yliopisto, nina.mesiranta@tuni.fi

${ }^{\mathrm{d}}$ Kasvatustieteellinen tiedekunta, Helsingin yliopisto, anna.kouhia@helsinki.fi

${ }^{\mathrm{e}}$ Kasvatustieteellinen tiedekunta, Helsingin yliopisto, minna.autio@helsinki.fi

f Johtamisen ja talouden tiedekunta, Tampereen yliopisto, elina.narvanen@tuni.fi
} 
kiertotalouden keinoin eivät ole edenneet (Haas ym. 2015). Tätä havainnollistaa vaikkapa se, että arvioiden mukaan vain yhdeksän prosenttia materiaaleista käytetään uudelleen (The Circularity Gap Report 2019). Maailmantalous perustuukin tällä hetkellä pääosin lineaariseen malliin, jossa tuotetaan, käytetään ja hukataan materiaaleja ja joka ennen pitkää johtaa kriittisten mineraalien ja metallien, kuten kuparin tai nikkelin ehtymiseen (mm. Prior ym. 2012; Northey $y m$. 2018). Materiaalisten resurssien niukkuus tulee jatkossa vaikuttamaan merkittävästi siihen, miten pystymme täyttämään esimerkiksi ravintoon ja suojaan liittyvät perustarpeemme. Uudenlaiset jäsennykset ihmisten ja materiaalien välisistä vuorovaikutussuhteista avaavat keinoja, joiden kautta voitaisiin oppia elämään kestävästi materiaalien kanssa. Esimerkiksi Jacobsen ja Hansen (2019) ovat painottaneet, että materiaalisen maailman ymmärtämisellä on tärkeä merkitys kestävän kulutuksen (ml. ilmastonmuutos) tutkimuksessa. Myös Evans (2019) on tuonut esiin kulutustutkimuksen merkitystä ekologisen kriisin tarkastelussa (antroposeeni/kapitaloseeni-keskustelu). Hänen mukaansa lähes kaikkea toimintaa, johon liittyy resurssien käyttöä, voidaan nähdä "kulutuksena". Arvioimalla uudelleen kulutuskulttuurin eettistä pohjaa sekä ylilyöntejä (a culture of excess, mt.) kulutustutkimus voi tarjota välineitä kestävämmän kulutuksen teorioiden muotoiluun.

Lähestymme tässä artikkelissa yllä esitettyä problematiikkaa monitieteisesti ammentaen kulutuksen ja arjen käytäntöjen tutkimuksesta sekä kasvatus-, kotitalous- ja käsityötieteiden kentiltä. Tiedostamme, että termit 'kuluttaja' ja 'kuluttaminen' tai 'resurssit' eivät ole ongelmattomia keskusteltaessa kestävistä tavoista olla vuorovaikutuksessa ehtyvien tai muuntuvien materiaalien kanssa (ks. esim. Salminen \& Vadén 2013, 2018; Pulkki 2017; Sachs 2017). Viitatessamme ihmistoimijoihin kuluttajina ja kirjoittaessamme materiaalisuhteista kestävän kuluttamisen kautta tuomme esiin pyrkimyksemme osallistua materiaalien käyttöön liittyviin keskusteluihin erityisesti kestävän kulutustutkimuksen ja kulutussosiologian alueilla, missä kyseisten termien käyttö on vakiintunutta (Shove 2010; Shove ym. 2012; Warde 2015; Evans 2018; Jacobsen \& Hansen 2019). Kuten Røpke (2009) on painottanut, lähes kaikkiin käytäntöihin sisältyy aineellisten resurssien käyttöä riippumatta siitä, luokitellaanko toiminta tuotannoksi vai kulutukseksi. Lisäksi ihmiset tyypillisesti ajattelevat olevansa pikemminkin osallisia mielekkäissä käytännöissä (esim. syöminen, nukkuminen, liikkuminen, lapsista huolehtiminen, ostoksilla käynti) kuin kulutuksessa. Kuluttaminen ei siis ole pelkästään tavaroiden tai palveluiden ostamista, vaan se sisältää erilaisia materian kanssa vuorovaikuttamisen tapoja ja tasoja, joissa materiaalit muokkautuvat, kuluvat, hajoavat ja saavat uusia ilmenemismuotoja (Evans 2018).

Tämän pohjalta keskeinen tavoitteemme artikkelissa onkin syventää ymmärrystä kuluttajien vastavuoroisista tavoista elää materiaalisten resurssien kanssa sekä tuoda keskusteluun näkökohtia materiaalien aktiivisesta toimijuudesta (Lehtonen 2008, 2015). Lähtökohtanamme on ajatus siitä, että materiaalitajun kautta kuluttajat oppivat uudenlaisia tapoja (consumer-learners, Selby \& Kagawa 2018; Autio 2019, Kortesalmi \& Autio 2019), käsityksiä ja suhteita materiaalien kanssa elämiseen. Pyrimme kohti näitä tavoitteita kehittelemällä uutta materiaalitajun käsitettä, jonka määrittelemme pragmatistista $(\mathrm{mm}$. Dewey 1916, 1938, 1958) ja uusmaterialistista (mm. Grosz 2005; Barad 2007; Bennett 2007, 2010; Puig de la Bellacasa 2017) teoretisointia hyödyntäen tilanteiseksi, vastavuoroiseksi ja alati muuttuvaksi sekä jaettua toimijuutta sisältäväksi ymmärrykseksi materiaalien olemuksesta ja niiden kanssa olevaksi tulemisesta. Pragmatismiin nojaten teoreettisena tavoitteenamme on rakentaa materiaalitajun käsitettä ymmärrykseksi toiminnasta, jossa ihmiset oppivat reflektiivisesti (Dewey 1916, 1933 [1960], 1938) muokkaamaan tapojaan olla ja elää arjessaan materiaalien kanssa sekä ratkomaan tässä vuorovaikutuksessa esiin nousevia ristiriitoja ja jännitteitä.

Käyttämällä termiä 'uusmaterialismi' haluamme puolestaan korostaa materiaalisuuden teorioiden ontologista käännettä sekä ajatusta materiaalien jatkuvista "tulemisista" ja ennalta määrittämättömien materiaalien olennaisesta läsnäolosta (tai mahdollisesta 
poissaolosta) sosiaalisissa järjestelyissä. Uusmaterialismiin liitämme tässä yhteydessä erilaisista käsitteellisistä materiaalisuuden teorioiden suuntauksista empiirisen ontologian (empirical ontology, Law \& Lien 2013; ks. myös Mol 2002 ja 2008 - näissä jatkokehitetään empiirisellä ja ontologisella painotuksilla toimijaverkkoteoriaa), vitaalin materialismin (vital materialism, Bennett 2007, 2010) sekä spekulatiivisen realismin ja ajatuksen hoivasta (Puig de la Bellacasa 2017), joita tässä tekstissä käsittelemme osana materiaalitajun käsitteellistä kehitystyötä. Korostamme määrittelyssämme materiaalien (Mattila ym. 2019) ja kuluttajan (kehollista) toimijuutta (Jacobsen \& Hansen 2019) sekä näiden välistä vuorovaikutusta (ts. jaettua toimijuutta) muutoksessa kohti kestävämpää ja turvallisempaa arkea. Näin artikkelimme voidaan sanoa täydentävän myös käytäntöteoreettista kestävän kulutuksen tutkimusta, jossa ensisijaisesti kuluttajalla on aktiivinen rooli käytäntöjen kantajana ( $\mathrm{mm}$. Sahakian \& Wilhite 2014; Matschoss ym. 2019).

Artikkelimme on jäsentynyt seuraavasti: Tarkastelemme ensin kuluttajien ja materiaalien välisten suhteiden rakentumista kulutustutkimuksen kontekstissa. Tämän jälkeen kuvaamme materiaalitajun käsitteellistä taustaa suhteessa lukutaidoista käytäviin keskusteluihin eri tieteenaloilla. Näiden keskustelujen sekä teoreettisten vaikutteidemme pohjalta päädymme rakentamaan materiaalitajun määritelmän neljä ulottuvuutta (tilanteisuns, ajallisuus, eloisuns ja kehollisuus), joihin liittyen nostamme esiin empiirisiä kytköksiä jatkotutkimuksen aihioiksi. Tarkastelemme tässä artikkelissa materiaalitajun käsitettä erityisesti kestävyyden näkökulmasta.

\section{Kuluttajien ja materiaalien kestävä suhde}

Määrittelemme kestävän kuluttamisen joustavaksi, tasapainoiseksi ja kontekstisidonnaiseksi lähestymistavaksi, jossa korostuvat esimerkiksi resurssien kestävä käyttö, elämänlaadun parantaminen ja ylikulutuksen välttäminen (Lim ym. 2017, s. 71). Viime vuosina kestävää kulutusta on tarkasteltu erityisesti käytäntöteoreettisista näkökulmista käsin (Røpke 2009; Shove 2010; Sahakian \& Wilhite 2014; Phipps \& Ozanne 2017). Tästä näkökulmasta kestävä kuluttaminen voidaan ymmärtää prosessina, johon liittyy käytäntöjä konkreettisesta toiminnasta (esim. hankkiminen ja poisheittäminen) arvottamiseen ja merkitysten luomiseen (Warde 2017; Evans 2018). Erityisesti tutkimuskohteena ovat olleet arkiset käytännöt, kuten energiankulutus (Shove 2010; Gram-Hanssen 2011), veden kulutus (Phipps \& Ozanne 2017), pyykinpesu (Jack 2013) ja ruoanlaitto (Mattila ym. 2019; Torkkeli ym. 2020).

Paitsi kulutusobjekteihin, kuluttajat voivat olla suhteessa myös esineiden materiaaleihin, muotoiluun ja markkinointiin (Ferreira \& Scaraboto 2016; Scaraboto ym. 2016). Näissä tarkasteluissa materiaalit ovat kuitenkin jääneet lähinnä erilaisiksi kuluttajien hallitsemiksi resursseiksi ja/tai kuluttajien toiminnan konteksteiksi. Myös kuluttajien ja materiaalien välisten suhdeverkostojen rakentumisen ja toimintamekanismien syvällinen ymmärtäminen on jäänyt vähäiseksi (vrt. Koskinen ym. 2018; Fuentes \& Sörum 2019; Mattila ym. 2019). Vaikka materiaalit ovat erottamaton osa käytänteitä (Shove ym. 2012), käytäntöteoriassa kuluttajalle on usein osoitettu ensisijainen aktiivinen rooli käytänteiden kantajana. Materiaalitajun käsitteessä tämä täydentyy uusmaterialismista ja pragmatismista ammentaen materiaalien aktiivisella toimijuudella sekä tilanteisella ja vastavuoroisella oppimisella yhdessä materiaalien kanssa. Keskeinen argumenttimme on, että muutosprosessien ja oppimisen teoretisointia hyödyntävät näkökulmat (mm. Janhonen ym. 2018; Kaljonen ym. 2018; Kaljonen ym. 2019) sekä materiaalien aktiivisten toimijuuksien aiempaa syvällisempi huomiointi (mm. Scott ym. 2014; Evans 2018; Koskinen ym. 2018; Mattila ym. 2019) vievät eteenpäin keskustelua siitä, miten uutta, kestävää materiaalisuhdetta voitaisiin rakentaa. Vaikka materiaalisuuden voidaan nähdä koostuvan tietynlaisista fyysisistä ominaisuuksista, ei kaikkia materiaalien merkityksiä voida kuitenkaan palauttaa näihin ominaisuuksiin. Materiaalien läsnäolo voi näyttäytyä sekä materian ilmenemisenä että poistumisena 
(esim. Tanhuanpää 2017), kuten esimerkiksi ruoan valmistaminen ja sen syöminen. Siksi materiaalien merkityksellistymistä ja olemuksellisuutta on tulkittava ja määriteltävä jatkuvasti uudelleen.

Yllä kuvattua kestävän kulutustutkimuksen keskustelua jatkaen, tavoitteenamme materiaalitaju-käsitteen hahmottelussa on kehittää ja tuottaa uudenlaista ajattelua, jota voidaan hyödyntää kestävän oppimisen, kasvatuksen ja kulutustutkimuksen kentillä (Kortesalmi \& Autio 2019). Pyrkimyksenämme on lisätä ymmärrystä materiaalisuhteista ja niiden jatkuvista (uudelleen)määrittelyistä. Materiaalitaju-käsitteen määrittelyn lähtökohtana on ajatus siitä, että ihmiset joutuvat väistämättä arjessaan erilaisiin vastavuoroisiin ja paikoin ristiriitaisiinkin suhteisiin materiaalien kanssa. Toisaalta monet arjen toiminnot ovat kuluttajille automaattisia tai ne vaativat hyvin vähän tietoista harkintaa ja reflektiota, myös suhteessa kestävään kuluttamiseen (Janhonen ym. 2018 viitaten Dewey 1916, 1958; ks. myös Southerton, Warde \& Hand 2004). Arjen rutiinien ja erilaisten kuluttamiseen sitoutuneiden toimintojen tiedostaminen tuo ne "tajun" - tässä tapauksessa materiaalitajun - piiriin. Seuraavaksi kuvaamme materiaalitajun käsitteellistä taustaa suhteessa lukutaidoista käytäviin keskusteluihin eri tieteenaloilla sekä täsmennämme, miten materiaalitajun käsite rakentuu suhteessa materiaalilukutaito-käsitteen ajankohtaisiin sovelluksiin.

\section{Materiaalitaju osana lukutaitoihin kytkeytyvää keskustelua}

Materiaalitajun taustalla vaikuttavat keskustelut alunperin UNESCO:n lukutaidon (literacy) määritelmästä (UNESCO Education Sector Position Paper 2003) ja sen kritiikistä. Käsitteellisesti materiaalitaju asemoituukin osaksi jatkumoa, jossa kuluttajien arjen osaamista on tarkasteltu esimerkiksi terveystajun (mm. Hoikkala ym. 2005; Puuronen 2006; Ojajärvi 2015) ja ruokatajun (mm. Janhonen ym. 2018; Kauppinen 2018) käsitteiden kautta. Ymmärrämme suomen kielen sanan "taju” toiminnassa ja toiminnan kautta kehkeytyväksi kontekstuaaliseksi ymmärrykseksi ja siten sekä kognitiivisia että kehollisia elementtejä sisältäväksi osaamiseksi (ks. Janhonen ym. 2018). Materiaalitaju on elämistä, olemista ja oppimista (ts. muutosta) suhteessa materiaaleihin ja yhdessä materiaalien kanssa. Se ei paikannu vain yksilön tietoihin ja taitoihin, vaan on tilanteessa ja suhteessa syntyvää sekä joustavasti ja vuorovaikutteisesti materiaalien kanssa muokkautuvaa. Näemme materiaalit eloisina ja aktiivisina toimijoina, joiden tulkinnat ja olemuksellisuus muodostuvat kerroksellisesti ja kontekstuaalisesti, aina suhteessa tilanteiseen materiaaliseen vuorovaikutukseen. Tarkastelemalla kestävää kuluttamista erilaisten materiaalisuuksien avulla on tarkoituksenamme jatkaa ja kehittää edelleen myös materiaalilukutaidon käsitteen kautta aiemmin käytyä keskustelua ihmisten ja materiaalien välisistä suhteista.

Materiaalilukutaito-käsite (material literacy) voidaan määritellä kyvyksi purkaa ja tulkita materiaalisten rakennelmien merkityksellisyyttä sekä niiden fyysisyyttä ja aineellisuutta (Rekrut 2006, s. 11). Empiirisessä tutkimuksessa materiaalilukutaidon käsitettä on käytetty erityisesti arkistodokumenttien tutkimisessa tarkoittamaan historiallisten dokumenttien uudelleen lukemista ja tulkintaa (esim. Kuipers 2004; Dever 2014). Viimeisimmissä keskusteluissa käsitettä on sovellettu myös designtutkimuksen alalle, jossa se liitetään ymmärrykseen erilaisten tuotteiden materiaaleista, valmistusprosesseista ja käytettävyydestä (Solanki 2018, 2019, 2020). Designtutkimuksen kentässä materiaalilukutaito liittyykin erityisesti kestävien ratkaisujen sekä tuotteen elinkaaren pohtimiseen: mistä raaka-aineet tulevat, miten materiaaleja käytetään, miten ne hajoavat ja millaisia ovat mahdollisuudet materiaalien kierrätykseen ja uusiokäyttöön.

Vaikka materiaalilukutaitoon on löydettävissä joitain viittauksia julkisessa keskustelussa ja tutkimuksissa, ei sitä kuitenkaan ole vielä tähän mennessä sovellettu yhtä laajasti kuin esimerkiksi ruokalukutaito-käsitettä. Lukutaito-jälkiliitteisten käsitteiden saamaan kritiikkiin nojaten (mm. Kimura 2011; Ojajärvi 2015; Vaitkeviciute ym. 2015; Truman $y m$. 2017) pyrimme materiaalitaju-käsitteen avulla siirtämään huomion kuluttajaa 
yksilönä ja/tai käytänteiden kantajana painottavista lähestymistavoista kohti entistä vahvempaa situationaalista ja interaktiivista ymmärrystä kestävästä kuluttamisesta, missä materiaalit yhdessä kuluttajien kanssa muodostavat moninaisia ja -muotoisia suhteita (vrt. Fuentes \& Sörum 2019). Seuraavaksi syvennämme sitä, miten pragmatismista ja uusmaterialismista ammennetut vaikutteet ovat auttaneet meitä täsmentämään materiaalitajun määritelmää.

\section{Materiaalitaju pragmatismin ja uusmaterialismin risteyskohdassa}

Materiaalitajun määritelmämme ammentaa teoreettisesti uusmaterialistisesta ja pragmatistisesta lähestymistavasta. Näiden vaikutteiden yhdistämisen potentiaali liittyy niiden tarjoamaan mahdollisuuteen kohdistaa huomio situationaalisiin kohtaamisiin (ts. tilanteisuuteen), eli niihin hetkellisiin tapahtumiin, joissa tietävät, tuntevat, muistavat ja oppivat ihmiskehot kohtaavat monenlaisia materioita. Pragmatismissa huomio kiinnittyy (oppivan ihmistoimijan) vastavuoroiseen ja jatkuvaan vuorovaikutukseen (ts. transaktioon) ympäröivän todellisuuden kanssa (Dewey 1916; ks. myös Tarrant \& Thiele 2016; Van Poek ym. 2020, s. 306). Pragmatismin kautta oppimista eli muutosta kohti kestävää kuluttamista on mahdollista tarkastella myös esimerkiksi kokeilevana yhteiskehittämisprosessina (Kaljonen ym. 2018), käytännön toiminnassa ilmenevien jännitteiden ratkaisemisena sekä syntyneiden ratkaisumallien käytännön toimivuuden testaamisena (Janhonen ym. 2018). Oppimisen näkökulman sisällyttäminen materiaalitajun käsitteeseen syventää sen ajallista ulottuvuntta korostaen oppimisen asteittain syvenevää ja monimutkaistuvaa luonnetta (mt.). On kuitenkin tärkeää huomioida, että kaikki muutos ei välttämättä ole toivottavaa (esim. kestävyyden suhteen tarkasteltuna kestäviä käytäntöjä edistävää) ja että kaikkea muutosta ei voida suoraviivaisesti määritellä oppimiseksi (Elkjaer 2008). Toisaalta oppimista ei myöskään voida yksioikoisesti määritellä muutoksena toiminnassa, sillä se voi saada myös muita piirteitä, esimerkiksi syvällisemmän ymmärryksen muodossa (mt., ks. myös Janhonen ym. 2018). Tähän liittyvää pohdintaa jatkamme materiaalitajun ajalliseen ulottuvuuteen liittyvän kuvauksen yhteydessä seuraavassa alaluvussa.

Käytäntöjen moninaisuus ja suhteellisuus sekä jatkuva muutos ovat läsnä myös uusmaterialistisessa teoretisoinnissa (mm. Law \& Lien 2013; Mattila ym. 2019). Uusmaterialismin voidaan kuitenkin sanoa täydentävän pragmatismia kiinnittämällä erityistä huomiota siihen, että materiat eivät ole ainoastaan toiminnan kohteita, vaan myös eloisia ja muuntuvia asioita, jotka itsessään vaikuttavat aktiivisesti tilanteisiin ja suuntaavat toimintaa. Lisäksi uusmaterialismi suuntaa huomion kuluttajien kehollisunden ja aistien tarkasteluun tilanteisissa kohtaamisissa materiaalien kanssa (esim. Mol 2002, 2008; Barad 2007; Bennett 2007, 2010; Scott ym. 2014; Puig de la Bellacasa 2017).

Yllä kuvattuun teoreettiseen taustaan nojaten eli pragmatismia ja uusmaterialismia yhdistäen määrittelemme materiaalitajun käsitteelle neljä keskeistä ulottuvuutta: tilanteisuus, ajallisuus, eloisuus ja kehollisuus. Sekä pragmatistisessa että uusmaterialistisessa tarkastelutavassa kompleksinen vuorovaikutus suhteessa ympäröivään maailmaan liittää materiaaleihin lisäksi neuvottelunvaraisia merkityksiä ja määrittelyjä, joiden tulkintaan ja uudistamiseen kuluttajat arjessaan osallistuvat (yhdessä erilaisten materiaalien kanssa) pyrkiessään toimimaan vastuullisesti (ks. uusmaterialistisesta tulkinnasta Koskinen ym. 2018; Mattila ym. 2019). Uusmaterialismiin nojaten materiaalisuhteet voidaan nähdä monimutkaisten suhdeverkostojen järjestelyinä, joissa niiden muuttumattomuus tai pysähtyneisyys riippuu niiden hienovaraisesta ja/tai vähittäisestä muuttumisesta (Law \& Singleton 2005). Toisin sanoen, sen sijaan, että korostetaan esineitä ja niiden materiaalisuutta sinänsä (esim. Appadurai 1986, Kopytoff 1986; Miller 2005) tai niiden omistamista (esinesuhde, "materian taju" perinteisesti materialismina ymmärrettynä), uusmaterialistiset teoriat korostavat materiaalisuhteiden hetkittäistä, vuorovaikutteista, avointa ja jännitteistä luonnetta. 
Ajatus materiaalien aktiivisesta toimijuudesta on uusmaterialistisessa perinteessä keskeinen ja se liittyy ei-inhimillisten, elollisten (esimerkiksi eläimet ja kasvit) ja elottomien esineiden ja materiaalien toimijuuteen (agency). Toimijuudella ei tarkoiteta sitä, että materiaaleilla voisi olla aikomuksia tai päämäärï samalla tavalla kuin ihmisillä. Sen sijaan toimijuudella viitataan materiaalien ja esineiden kykyyn puuttua tai vaikuttaa muihin toimijoihin - niin muihin materiaaleihin ja esineisiin kuin ihmistenkin toimintaan (Borgerson 2013, s. 132). Toisaalta uusmaterialistisissa lähestymistavoissa toimijuutta ei myöskään pidetä yksittäisille toimijoille kuuluvana ominaisuutena vaan enemmänkin jaettuna eri toimijoiden välillä ja tilanteisesti syntyvänä (esim. Lehtonen 2015; Syrjälä ym. 2016). Kun yritämme muuttaa käytäntöjä kestävämpään suuntaan, tulisi erilaiset toimijuudet sekä niiden monitahoiset yhteenkietoumat ja (keskinäiset) riippuvuudet ottaa huomioon. Kohti tämän moninaisuuden ymmärtämistä ja käsitteellistä jäsentämistä olemme materiaalitaju-käsitteen ulottuvuuksien kautta pyrkineet.

Pragmatismista ammennetut vaikutteet näkyvät materiaalitaju-termissä jatkuvasti muuttuvana vuorovaikutuksena ympäröivän sosiaalisen, kulttuurisen ja materiaalisen maailman kanssa. Tässä pragmatismiin nojaavassa määrittelyssä voidaan nähdä yhtäläisyyttä uusmaterialistiseen tapaan tarkastella toimijuuksia - kohdistuen etenkin siihen, miten erilaiset materiaalit tulevat olemassa oleviksi suhteellisissa, moninaisissa ja jatkuvasti muuttuvissa käytännöissä (mm. Law \& Lien 2013; Mattila ym. 2019). Kuten mainittu, Deweyn pragmaattinen oppimisteoria $(1916,1938)$ tarjoaa lisäksi välineitä toiminnallisen, situationaalisen ja kokemuksellisen oppimisen, mukautuvan ja luovan ongelmanratkaisun sekä toiminnassa nousevien jännitteiden ratkomisen tarkasteluun ${ }^{1}$. Määrittelemme rutiinien muutoksen soveltamalla Deweyn (1916, 1938) ajatuksia refleksiivisestä ajattelusta ja toiminnasta. Tämän pohjalta on mahdollista tarkastella sitä, miten kuluttajat löytävät ratkaisuja arjen uudelleenjärjestelyyn tilanteissa, joissa aiemmat rutiinit tulevat kyseenalaistetuksi tai joissa ne eivät enää toimi käytännössä (ts. niiden muuttaminen on välttämätöntä). Ratkaisujen löytäminen tällaisen refleksiivisen toiminnan avulla avaa mahdollisuuden ymmärtää ja lähestyä kestävyyteen pyrkivien materiaalisuhteiden rakentumista kokeilevana, vuorovaikutteisena ja sopeuttavana toimintana, jonka kautta voidaan esimerkiksi vähentää - tai erilaisten materiaalisuhteiden epäonnistuneiden järjestelyjen seurauksena synnyttää -ruokahävikkiä (Koskinen ym. 2018; Mattila ym. 2019). Deweyläinen pragmatismi voidaan lisäksi nähdä teoreettisena kehyksenä, joka yhdistää merkityksellisten käytäntöjen säilyttämisen määritelmään elinikäisestä oppimisesta muuttuvassa maailmassa, tarjoten siten hyödyllisiä välineitä kestävyyskasvatuksen toteutukseen ja oppimisen tukemiseen esimerkiksi kouluissa (Tarrant \& Thiele 2016).

Vaikka pragmatismiin usein viitataan klassisena kasvatuksen teoriana ja filosofiana, on sitä sovellettu myös muun muassa tutkittaessa kestävyysmuutosta joukkoruokailun kontekstissa (Kaljonen ym. 2018; Kaljonen ym. 2019), pohdittaessa kulutustutkimuksen tulevaisuuden suuntaviivoja (Silcock 2015), tarkasteltaessa eettistä kuluttamista (Hiller \& Woodall 2018; Fuentes \& Sörum 2019) sekä tutkittaessa kuluttajien sosiaalista oppimista ja jaettua asiantuntijuutta verkkoympäristöissä (Jayanti \& Singh 2010). Näemme nämä moninaiset tutkimusesimerkit inspiraation lähteinä myös pohdittaessa materiaalitajun empiiristä potentiaalia ja sovelluskohteita. Seuraavassa luvussa kuvaamme tarkemmin materiaalitaju-käsitteen keskeisiä ulottuvuuksia (tilanteisuus, ajallisuus, eloisuus, kehollisuns). Havainnollistamme ulottuvuuksia empiiristen esimerkkien kautta sekä jatkamalla pohdintaa siitä, kuinka elää kestävästi materiaalien kanssa (Lehtonen 2015; Kinnunen 2017; ks. myös Koskinen ym. 2018).

${ }^{1}$ Esimerkiksi kulutustutkija Hazel Kyrk (1923) kehitti kuluttajakasvatusta Deweyn ajatteluun pohjautuen ja hän tulkitsi kuluttajat toimijoiksi, jotka kykenevät arvioimaan valintojaan. Dewey (1933) näki, että ei-reflektiivinen toiminta - rutiinit - ohjaavat paljolti käyttäytymistä. Kun rutiinit murtuvat, syntyy jännite, jota ihminen joutuu pohtimaan eli arvioimaan, miten edetä tilanteessa. Pulmaan syntynyt ratkaisu ja toiminta rakentuvat oppimisprosessin tulokseksi. 


\section{Materiaalitaju arjen materiaalisuuksien hahmottamisen tukena}

Kotitalouksissa tapahtuvan kulutuksen ympäristövaikutukset ovat merkittävimmät syömisen, asumisen, tekstiilien huollon ja liikkumisen osalta ( $\mathrm{mm}$. Lorek 2009; Salo \& Nissinen 2017; Akenji 2019). Vallitsevassa kestävyysvajeessa korostuvat tavat, joilla kotitaloudet käyttävät materiaaleja ja joilla arki on vuorovaikutuksessa materiaalisten resurssien, kuten ruoan, muovin, tekstiilien sekä kodin pintamateriaalien ja kemikaalien, kanssa. Tähän kytkien hahmotamme materiaalitajun neljä keskeistä ulottuvuutta seuraavasti:

Tilanteisuus kohdistaa huomion toiminnan kontekstisidonnaisuuteen ja korostaa sellaisten empiiristen sovellusten tärkeyttä, jotka tarkastelevat käytännönläheisiä toimintaprosesseja sekä jatkuvasti uudelleen syntyviä ja muuntuvia kohtaamisia materiaalien kanssa (Janhonen $y m$. 2018; Torkkeli $y m$. 2018). Uusmaterialismista ammentaen materiaalitajun tilanteisuus on materiaalien kanssa jaettua toimijuutta eli sellaista toimintaa, johon myös materiaalit aktiivisesti vaikuttavat. Lisäksi se on materiaalien kanssa jaettua tilanteista ymmärrystä eli tajua, jossa tieto ja kognitio ei paikannu vain ihmisyksilöön, vaan jossa myös materiaaleihin voi "tallentua" osaamista rutinoituneiden prosessien suorituksissa (Groth 2017). Materiaalitajua voi tarkastella myös kollektiivisesti rakentuvana eli osana laajempia institutionaalisia tai kulttuurisia käytäntöjä. Tämän laajemman kontekstin huomioiminen on nostettu tärkeänä näkökulmana esiin myös ajankohtaisissa kestävyyteen liittyvissä keskusteluissa ja määritelmissä (esim. Mäkelä \& Niva 2015).

Ajallisuus viittaa toisaalta materiaalitajun historiallisuuteen, toisaalta jatkuvaan muutokseen, jonka kautta tulee näkyväksi tarve myös pitkittäistutkimuksille eli aikajänteeltään pidempiaikaisten muutosprosessien tarkastelulle. Materiaalitajun historiallisuus voi tarkoittaa myös sitä, että materiaaleihin tai materiaalisiin artefakteihin on tallentunut kollektiivista ja ylisukupolvista materiaalista osaamista (esim. vaatteiden mallit, joiden alkuperä voi olla satoja vuosia vanha). Ajallisuuden ulottuvuus tuo näkyväksi sen, että muutos ei ole aina kronologista, jännitteetöntä, suoraviivaista, ennakoitavissa olevaa tai kumuloituvaa, vaan se voi olla myös säröilevää, poukkoilevaa, taantuvaa, hajoavaa tai hidastuvaa. Pragmatismin teoreettisten vaikutteiden kautta toiminnassa esiin nousevat väistämättömät jännitteet voidaan nähdä myös muutoksen mahdollisuuksina ja myönteisinä asioina, joiden kautta toiminnan uudelleenmäärittely voi tulla mahdolliseksi (Janhonen ym. 2018; Kaljonen ym. 2018; Kortesalmi \& Autio 2019). Näitä jännitteitä on mahdollista tarkastella eri tasoilla, kuten osana kotitalouden arkista toimintaa tai laajemman sosiomateriaalisen ja kulttuurisen kontekstin, kuten vaikkapa yhden koulun, suomalaisen ruokajärjestelmän tai globaalin kestävyyshaasteen näkökulmasta. Mitä laajempia tarkastelukulmia rajataan, sitä tärkeämpää on sisällyttää tarkasteluun myös materiaalitajun tilanteisuuteen kytkeytyvä ulottuvuus. Ajallisuuden ulottuvuuteen liittyen voidaan hahmotella myös ajatusta materiaalien muistista eli joustavuudesta, palautumisesta tai pysyvästä olomuodon muutoksesta suhteessa toimintaprosesseihin.

Eloisuns tarkoittaa materiaalien kykyä muuntua, joko ihmisen toiminnan vaikutuksesta tai tästä irrallaan (esim. ruoan homehtuminen). Eloisuuden ulottuvuudessa tulee erityisen vahvasti näkyväksi uusmaterialismin ajatus materiaalien aktiivisista toimijuuksista tai jaetusta toimijuudesta materiaalien kanssa: materiaalit vaikuttavat toimintaamme, joskus jopa vastustavat sitä tai pakottavat meitä muuttamaan tai mukauttamaan toimintaamme suhteessa niihin. Materiaalitajun käsitteeseen kytkeytyvä määritelmä oppimisesta ei paikannu vain oppivien ihmisyksilöiden kognitioon, vaan oppiminen tapahtuu yhdessä materiaalien kanssa eläen. Metafora "materiaalien kanssa tanssimisesta" kuvaa havainnollisella tavalla tätä eloisuuden ulottuvuutta (Mattila ym. 2019). Eloisuuden kautta konkretisoituu se, miten myös materiaalit voivat "puhua" ja "tajuta" eli kommunikoida (kulloinkin käytössä olevin keinoin) (esim. puiden juuristot tai sienirihmastot voivat olla yhteydessä toisiinsa ja viestiä keskenään).

Kehollisuus tuo esiin niitä moninaisia tietämisen ja kokemisen tapoja, joiden kautta olemme vuorovaikutuksessa materiaalien kanssa (ks. esim. Koskinen ym. 2018). Lisäksi tämä 
ulottuvuus korostaa sitä, miten kehomme on jatkuvasti vuorovaikutuksessa materiaalien kanssa, vaikka emme välttämättä näkisi tai aistisi niiden ominaisuuksia. Kehollisuus myös havainnollistaa, miksi monia rutinoituneita arjen prosesseja voi olla haastava sanallistaa tai muuttaa (Torkkeli ym. 2018). Toisaalta materiaalien ja kehojen tilanteisissa kohtaamisissa voi piillä myös uuden oppimisen potentiaali, jos materiaaleja vaikkapa työstetään epätavanomaisin keinoin, jättäen tilaa leikkimieliselle ihmettelylle ja myös epäonnistumisille (Kouhia \& Janhonen 2019). Epätavanomaiset kohtaamiset materiaalien kanssa tekevät näkyväksi sitä, miten materiaalit eivät aina käyttäydy ennakoiduilla tai toivotuilla tavoilla, avaten samalla uusia mahdollisuuksia jäsentää ihmisten materiaalisuhteita ja osaamista (mt.), myös suhteessa kestävyyteen. Ruumiillisuuden (ts. ihmisten tai eläinten kehot) lisäksi kehollisuuden ulottuvuus viittaa myös laajemmin materiaalisiin olomuotoihin (esim. sienen kehollisuus on sen sienimäinen muoto ja veden "keho" voi saada ilmenemismuotoja myös höyrynä tai jäänä). Kehollisuus vie tilaa: se ilmenee fyysisesti eli ei ole vain kulttuuria, puhetta tai uskomuksia (vrt. ajallisuuden ulottuvuus, jonka voidaan sanoa olevan inhimillinen konstruktio, ts. absoluuttista aikaa ei voida sanoa olevan olemassa). Kehollisuuden ulottuvuus tuo materiaalitajuun myös ajatuksen materiaalien hoivaamisesta ja niistä välittämisestä (Puig de la Bellacasa 2017; Kinnunen 2018; Koskinen ym. 2018). Sen sijaan, että materiaalisuus näyttäytyisi kielteisenä materialismina - tuhlailevana elämäntapana ja kertakäyttökulttuurina - se voi näyttäytyä huolenpitona, joka voi edistää kestävämpää elämäntapaa ja kuluttamista (Evans 2019). Materiaalitajun affektiivinen puoli on kytköksissä kehollisuuteen ja se voi saada kielteisiä tai myönteisiä ilmenemismuotoja, kuten ällötys pilaantunutta ruokaa kohtaan tai ylpeys maljakosta, joka on "tuunattu" vanhasta lasipurkista.

Empiirisesti hahmotamme materiaalitajun neljä ulottuvuutta toisiinsa kietoutuneina ja risteävinä sekä vastavuoroisesti ja dynaamisesti toisiinsa vaikuttavina juonteina (ks. kuva 1). Kietoutuneisuudestaan ja risteävyydestään huolimatta näemme, että ulottuvuuksia on mahdollista erottaa analyyttisesti ja märitelmällisesti toisistaan, kuten olemme tässä artikkelissa käsitteellisen kehittelytyömme myötä hahmotelleet. Näin materiaalien kanssa elämisen kompleksisuutta ja jatkuvaa muutosta on mahdollista hetkellisesti kohdentaa ja purkaa empiirisen analyysin kannalta haltuun otettavaksi jäsennykseksi. Kuten kuva 1 havainnollistaa, voidaan ulottuvuudet nähdä myös toimintaprosessien juonteina, joiden

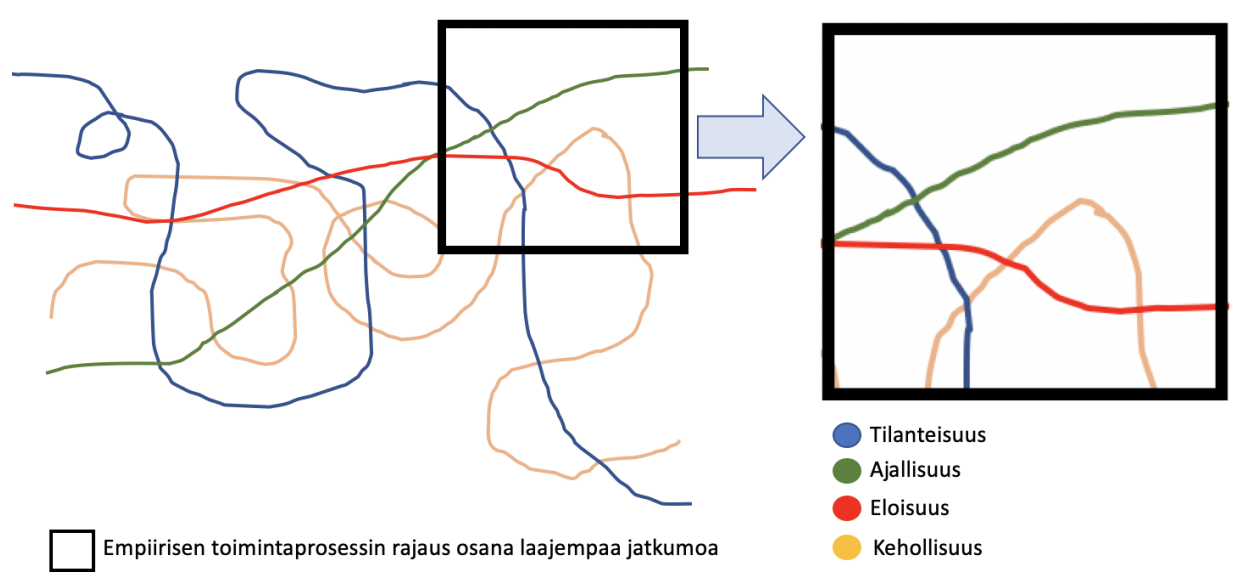

Kuva I. Materiaalitajun neljän ulottuvuuden (tilanteisuus, ajallisuus, eloisuus ja kehollisuus) havainnollistus osana kuvitteellista empiiristä toimintaprosessia.

Figure I. Illustration of the four dimensions of material sense (situationality, temporality, liveliness, corporeality) as a part of an imaginary empirical process of action. 
kautta materiaalien kanssa elämistä sekä materiaalitajun ulottuvuuksien keskinäisiä suhteita on mahdollista seurata tietyn empiirisen rajauksen kautta. Vaikka materiaalisuhteita voitaisiin tarkastella lukuisista erilaisista tulokulmista, on keskeinen argumenttimme tässä artikkelissa, että materiaalitaju jäsennyksineen tarjoaa kestävän kulutuksen tarkasteluun erityisen tarpeellisia ja hyödyllisiä työkaluja. Seuraavaksi tarkastelemmekin materiaalitajua ja sen keskeisiä ulottuvuuksia neljän kestävyyteen kiinteästi kytkeytyvän empiirisen esimerkin avulla.

\section{Pyykinpesu materiaalisena vuorovaikutuksena}

Jokapäiväiset arkiaskareet kuten pyykinpesu vaativat kuluttajilta kompetensseja, joita tukemalla voidaan edistää kestävää kuluttamista. Veden käyttöä kotitalouksissa voitaisiin pyrkiä vähentämään tukemalla kuluttajien materiaalitajua eli vaikkapa kykyä ottaa talteen ja hyödyntää harmaata vettä (vrt. Phipps \& Ozanne 2017). Pyykinpesun kontekstissa materiaalitajun tilanteisuus tarkoittaa sitä, että pyykinpesuun vaikuttavat moninaiset tekijät siitä, mitä ja miten ollaan pesemässä (materiaali, pesulämpötila), millaisia pesuaineita ja tarvikkeita pestävä materiaali edellyttää (esimerkiksi pesukoneessa vai käsin tai pelkästään tuuletus, pesupussit; hajustettu tai hajusteeton, ympäristöystävällinen vai ei, nestemäinen tai tabletti, pesupähkinät) ja ylipäätään se, milloin (ja mihin aikaan vuorokaudesta) pestään pyykkiä. Kestävän kuluttamisen näkökulmasta kuluttajalla voi olla tavoitteena mahdollisimman energiatehokas ja ympäristöystävällinen peseminen. Tilanteisuus näyttäytyy esimerkiksi, kun pestävässä vaatteessa onkin tahra, joka vaatii erilaista huomiota kuin tavallisesti ja siten haastaa aiempaa toimintaa. Kuluttaja voi joutua vaikkapa nostamaan väliaikaisesti aiemmin rutiininomaisesti käyttämäänsä pesulämpötilaa, vaikka se ei olekaan ympäristöystävällistä. Näin materiaalitajun tilanteisuus näyttäytyy myös jatkuvana neuvotteluna. Materiaalitajun tilanteisen ulottuvuuden huomiointi osana oppimisprosessia voisi tässä yhteydessä tarkoittaa esimerkiksi toimijoiden omiin arkisiin pyykinpesuprosesseihin liittyvien perustelujen ottamista lähtökohdaksi tuettaessa muutosprosessia kohti kestävämpiä kulutusvalintoja.

Materiaalitajun ajallinen ulottuvuus puolestaan tulee pyykkiä pestäessä näkyväksi vaikkapa siinä, miten erilaiset puhtauteen liittyvät normit, infrastruktuuri ja materiaaliset olosuhteet ohjaavat pyykinpesun tarvetta sekä siten energian kulutuksen tasoa (Phipps \& Ozanne 2017). Toisin sanoen, vaatteiden puhtautta ja pyykinpesun tiheyttä ohjaavat yhteisesti jaetut tavat, käsitykset ja käytänteet, jotka muotoutuvat ajassa. Materiaalitajun kehollisuuteen ja ajallisuuteen liittyvät ulottuvuudet tulevat näkyväksi sitä kautta, että vaatteiden kokeminen puhtaiksi tai likaisiksi muuttuu ajassa ja ajan myötä, jos konventioita muutetaan. Tähän liittyen Jack (2013, s. 411) on tutkinut, miten australialaisten kuluttajien käsitykset puhtaudesta muuttuivat, kun he pitivät farkkuja päällä vähintään viisi päivää viikossa kolmen kuukauden ajan käyttämättä vettä, energiaa tai kemikaaleja. Puhtauden ja likaisuuden raja alkoi muuttua, kun farkkujen pesemättä jättämisestä tuleekin hyväksyttyä. Jack painottaa myös yksilöiden kykyä tulla tietoiseksi ja joustaviksi käytänteiden uusintajiksi. Näin ymmärrys siitä, että vaatteiden puhdistamista voidaan myös vähentää, voidaan tulkita yhtenä sovelluksena materiaalin tuntemuksesta ja käytöstä.

Materiaalitajun eloisuuden huomioiminen voisi puolestaan tarkoittaa kuluttajien ymmärryksen tukemista kohti kompleksisten materiaalisten olosuhteiden ja vuorovaikutussuhteiden hahmottamista (vrt. Matschoss $y m$. 2019) sekä sen ymmärtämistä, että myös materiaalien ominaisuudet ovat mukana aktiivisesti vaikuttamassa pyykinpesun prosessien toteutumiseen. Materiaali (esimerkiksi villa tai farkkujen denim, jotka voi raikastaa pakastimessa) voi mahdollistaa sen, että vesipesun voi korvata muulla puhdistustavalla. Puhdistustuotteet, kuten esimerkiksi sappisaippua, voivat toimia apuna tahrojen puhdistamisessa.

Materiaalitajun kehollisuus hahmottuu sekä tiedostettujen aistimusten kautta (esim. miltä tuoksuu likainen tai puhdas pyykki, miten tahroja pitää mekaanisesti käsitellä, tai miltä 
tuntuu pyykki sen jälkeen, kun se on käynyt kuivausrummussa) että tiedostamattomina prosesseina (esimerkiksi fleece-vaatteen pesussa irtoavat mikromuovit). Kehollinen vuorovaikutus ihmisten ja materian välillä voi liittyä myös erilaisiin kokeiluihin tahrojen ja tuoksujen poistamiseksi vaatteista ilman pesua. Kestävän kuluttamisen näkökulmasta pesukoneen ja kuivausrummun käyttö voi olla myös tekijä, joka hidastaa materiaalitajun kehittymistä, kun vaatteet laitetaan sen enempää ajattelematta koneeseen ja kehollinen tietotaito ei pysy yllä tai kehity.

\section{Puu asumisen materiaalina}

Puukerrostalot ja niihin liittyvät materiaalit on nähty yhtenä keinoja pienentää kasvihuonekaasupäästöjä (Lehmann 2013). Puumateriaalia on käytetty perinteisesti asuintaloissa, mutta viime vuosikymmeninä kerrostalot on rakennettu pääosin betonista. Kun puurakentaminen yleistyy ja kerrostaloasuntojen materiaali onkin puuraaka-ainetta (CLT, cross-laminated timber), vaatii se kuluttajilta uudenlaista suhdetta materiaalin kanssa elämiseen - puu ääntelee, taipuu ja käyttäytyy seinäpintana eri tavoin kuin betonista valmistettu asunto ja talon seinäpinta (Viholainen ym. 2020). Puu materiaalina on eloisa, kun se muovautuu käytön (narisevat puutalojen lankut) tai sääolosuhteiden mukaan. Puumateriaali tuo esiin myös materiaalitajun historiallisen eli ajallisen ulottuvuuden (myös Jacobsen \& Hansen 2019), kun tarkastellaan materiaalien työstämisen historiaa vaikkapa hirsien veistämisen (ts. puun muokkaaminen kodin ja asumisen materiaaliksi) kautta. Viholaisen ym. (2020) tutkimuksessa ilmeni, että suomalaisten historiallinen sidos puuhun (esim. hirrestä valmistetut kesämökit, puun tuoksu ja äänet, muistot) on tärkeä osa asumiskokemuksen muodostumista moderneissa puukerrostaloissa. Voidaankin sanoa, että materiaalin ymmärrys eli taju pohjaa ajallisuuteen eri tavoin, kuten henkilöhistorian ja kansallisten traditioiden kautta.

Materiaalitajun määritelmään nojaten, myös puumateriaalin kanssa eläminen rakentuu kuluttajien arjen näkökulmasta tarkasteltuna tilanteisena, vastavuoroisena ja jatkuvasti kehkeytyvänä olemisena ja oppimisena yhdessä materiaalisten ominaisuuksien ja prosessien kanssa. Tämä voi tulla näkyväksi vaikkapa oppimisena suhteessa puutalon pinnan suojaamiseen kosteudelta, lämmöneristyksen toteuttamiseen tai kolhujen hiomiseen syysmyrskyn jäljiltä. Myös materiaalin kehollisuus rakentuu puumateriaalin osalta erilaiseksi kuin esimerkiksi kerrostaloasunnon betoninen pinta ja olemus tai vaikkapa lämmitysenergia. Puukerrostalon seinään voi kiinnittää helposti taulun, koska puu seinäpintana on pehmeä (Viholainen ym. 2020). Samalla tavoin, vaikka asunnon sisälämpötilan (viileys, kuumuus) voi tuntea iholla, niin puun tuoksu, äänimaisema, "pehmeys" sekä sidos historiallisiin kokemuksiin tekevät siitä kokemuksellisesti erilaisen kuin betonista. Kodin ja saunan lämmittäminen puulla tuntuu ja tuoksuu, mikä tuo esiin materiaalitajun kehollista ulottuvuutta.

\section{Ruokahävikin vähentäminen materiaalitajun näkökulmasta}

Ruokahävikin vähentäminen on yksi kestävän kehityksen keskeisistä haasteista ja koskettaa läheisesti kuluttajien arkea. Ruoka materiaalina on altis pilaantumiselle, mikä havainnollistaa sekä materiaalitajun eloisuuteen että ajallisuuteen liittyviä ulottuvuuksia ja samalla asettaa tietynlaisia reunaehtoja materiaalisuhteeseen (esim. Bennett 2007, 2010; ks. myös Ingold 2012). Eloisuus näkyy siinä, että esimerkiksi hävikkiuhanalaisella ruoalla on kyky kutsua käyttämään tai jättämään käyttämättä sitä (Koskinen ym. 2018). Toisaalta esimerkiksi jääkaapit ja pakastimet auttavat kuluttajaa pidentämään ruoan säilyvyyttä, mutta samalla ne vaativat kuluttajilta toiminnan koordinointia, jotta ruoka ei pilaantuisi (Mattila ym. 2019). Toimijuuksia tarkasteltaessa onkin huomioitava, että materiaalit sekä niistä valmistetut esineet mahdollistavat ja rajoittavat inhimillistä toimintaa. 
Ruokahävikin vähentämisessä ajallisuuteen kytkeytyy myös ajatus (kollektiivisesta) muistista eli siitä, miten esimerkiksi erilaisten rituaalien, arvojen ja tapojen kautta voi välittyä materiaalista osaamista jopa sukupolvelta toiselle (Sutton 2010). Ruokaan materiana voi kytkeytyä myös sensorista muistia: aistit voivat kannatella muistikuvia kokemuksellisista kohtaamisista materiaalien kanssa (Korsmeyer \& Sutton 2011; Koskinen ym. 2018). Näin vaikkapa tietyn maun maistaminen uudelleen voi palauttaa elävästi mieleen tilanteen, jossa maku on aiemmin koettu.

Toisaalta materiaalitajun ajallinen kehittyminen ruokahävikin kontekstissa voi näkyä myös laajemmin yhteiskunnallisissa keskusteluissa. Esimerkiksi luomalla positiivisia merkityksiä sosiaalisessa mediassa voidaan edistää kuluttajien ruokahävikin vähentämisen käytänteitä (Närvänen ym. 2018). Tämä voi ilmetä vaikkapa esittämällä hävikkiruoka herkkuna ja esteettisesti kauniina annoksina, mikä ottaa huomioon materiaalitajun eloisuuden ja ajallisuuden (mt.). Tuore viestintäkampanja "Rakasta joka murua" esimerkiksi vetoaa kuluttajien affektiiviseen ruokasuhteeseen ja herättelee hoivan tunteita ruokahävikkiä kohtaan (ks. myös Koskinen ym. 2018). Toisaalta, median kautta ihmisten arkea lähestyvät vaikuttamisen keinot eivät välttämättä huomioi ruokahävikin syntymisen tilanteisuutta ja sen kehollisuuteen (ja sitä kautta aisteihin) kytkeytyviä ominaisuuksia. Nämä kuitenkin liittyvät oleellisesti sekä ruoanlaiton käytäntöjen suorituksiin arjessa (Torkkeli ym. 2020) että totuttuihin tapoihin ymmärtää ruoan materiaalisuutta (ks. Kouhia \& Janhonen 2019). Ilman tätä ymmärrystä voi muutosta arkisissa käytännöissä olla haastava saada aikaan (Torkkeli ym. 2020). Kestävyysmuutokseen ja oppimisen tukemiseen liittyen ruokahävikin vähentäminen on myös erinomainen esimerkki rutinoituneesta arjen prosessista, jota ei-tiedostettujen toimintatapojen vuoksi voi olla haastava sanallistaa ja johon liittyvän tilanteisen tietoisuuden eli tajun lisääminen voisi olla keino tukea muutosta kohti kestävämpiä materiaalisuhteita (Janhonen ym. 2018).

\section{Elintarvikepakkausten kierrätys materiaalien virtana}

Muovi ja lasi ovat esimerkkejä materiaaleista, jotka voivat saada ihmisten arjessa monenlaisia ilmenemismuotoja ja toteutumisia, eikä niiden kanssa tai suhteessa niihin eläminen aina näyttäydy mustavalkoisesti joko kestävänä tai ei-kestävänä. Esimerkiksi arkiset valinnat suhteessa elintarvikepakkauksiin voivat olla myös toisiaan poissulkevia tai jännitteisiä (Lindh ym. 2016; Ketelsen ym. 2020). Materiaalien erilaiset käyttötilanteet ja vuorovaikutteisuuden muodot voivat myös seurata toisiaan ajallisesti ja tilanteisesti arjen materiaalivirrassa. Esimerkiksi pääosin hiekasta, kalkista ja soodasta valmistettu lasinen hillopurkki voidaan uusiokäyttää säilönnässä omassa kotitaloudessa, antaa uudelleentäytetty hillopurkki lahjaksi, keksiä uusi käyttötarkoitus purkille, kierrättää purkki lasijätteenä teollisuuden raaka-aineeksi tai purkki voi jäädä tarpeettomana ja hylättynä vuosikausiksi kaapinperälle (second cycles of consumption, esim. Evans 2019).

Muovi puolestaan on materiaalina helposti käsiteltävä ja muotoiltavissa, mikä selittää sen suosiota erilaisissa pakkauksissa. Ruokahävikin kontekstissa on nostettu esiin muovin rooli ruoan säilyvyyden parantajana (Humbert ym. 2009; Lindh ym. 2016). Toisaalta kotitalouksien arjessa on korostunut myös halu vähentää muovituotteiden käyttöä henkilökohtaisissa arjen valinnoissa osana minimalistista kuluttamisen eetosta (Meissner 2019). Viimeaikainen keskustelu muovin ympäristövaikutuksista sekä yhteiskunnalliset toimet muovijätteen vähentämiseksi (mm. muovikassien maksullisuuden lisääntyminen sekä tehostunut kotitalouksien muovijätteen keräys) ovat saaneet aikaan muutoksia sekä kuluttajien materiaalisuhteissa että arjen toiminnoissa, kuten kestokassin valitseminen kauppakassiksi muovikassin sijaan (Thomas ym. 2019) tai vaikkapa jogurttipurkin kannen ja pikarin lajitteleminen erikseen metalli- ja muovijätteeseen aikaisemman sekajätejakeen sijaan. Tällaiset uusina opitut tiedostavammat ja ympäristömyönteisemmät käyttäytymisen tavat ovat materiaalitajun näkökulmasta aina kuitenkin jatkuvassa muutoksen tilassa, 
sillä sekä materiaalit että niiden vuorovaikutteisuus elävät ja muuntuvat, korostaen materiaalitajun tilanteista ja ajallista luonnetta.

Kehittyvä materiaalitaju voi näyttäytyä konkreettisesti esimerkiksi kotitalouksien jätteenlajittelussa, jossa kodin jätepisteeseen on alettu kerätä metalli-, lasi-, keräyspaperi- ja pahvi- ja kartonkipakkausjakeen lisäksi yhä useammassa kotitaloudessa myös muovijätettä. Jo pelkkä muovijätteen lajittelu on tuonut materiaalitajun näkyväksi purkamalla ja uudelleen rakentamalla tapojamme kierrättää ja heittää pois erilaisia materiaaleja. Lisäksi näkyväksi ovat tulleet myös uudenlaiset, eri jätekategorioiden rajapinnoilla liikkuvat ja osittain niiden väleihin putoavat materiaalihybridit, kuten kartongista valmistetut jogurttija raejuustopurkit, joiden oikeaoppiminen lajittelu vaatii purkin huuhtelun lisäksi myös huuhtelusta vettyneen ( $\mathrm{ja}$ muoviin verrattuna eri tavalla eloisaksi tulleen) materiaalin kuivatuksen. Materiaalien kierrätys tiettyyn roskajakeeseen näyttäytyy arjen käytäntöinä (Thomas \& Sharp 2013), jota totutusta poikkeava kartonkipakkauksen erilainen olemuksellinen toimijuus haastaa ja horjuttaa. Tämä vaatii myös kuluttajilta uudenlaisia materiaalisia neuvotteluita ja kehollista arjen rajankäyntiä, kun roskajakeen materiaalit eivät ole selvärajaisia tai totutusti tunnistettavissa ja määriteltävissä esimerkiksi ulkonäön, värin tai tunnun perusteella. Kestävään kuluttamiseen liittyvissä käytänteissä onkin mukana jännitteitä ja ristiriitoja, joita materiaalitajun käsite voi tuoda näkyväksi.

\section{Materiaalitajun määritelmän kokoavaa tarkastelua}

Tiivistäen voidaan sanoa, että materiaalitajun määritelmä nostaa tarkasteluun ekologisesti kestävän tavan muodostaa ja ylläpitää materiaalisuhteita. Jäsennyksellämme emme pyri väittämään, että olisi olemassa yksi ainoa ja oikea tapa elää erilaisten materiaalien kanssa. Toisin sanoen, yllä annetuista empiirisistä esimerkeistä huolimatta emme määrittele materiaaleja selvärajaisina ja ehdottomina, kuluttajien tarpeita tyydyttävinä ja etukäteen määriteltyinä kokonaisuuksina, vaan hetkellisinä, moninaisia ja aktiivisina toimijuuksina, jotka synnyttävät jatkuvasti uudenlaisia olemisen muotoja (Mol 2002, 2008; Law \& Lien 2013). Hahmotamme materiaalitajun käsitteenä, jonka kautta voidaan tarkastella erilaisia materiaaleja lukuisista tulokulmista. Materiaalilla voidaan siis ymmärtää eritasoisia asioita, kuten komponentteja (kuidut), ainetta (puuvilla raaka-aineena) tai materiaaleja ja esineitä (tekstiilit, vaatteet). Siten vaikkapa esineisiin verrattuna, materiaalit ovat epämääräisempiä ja niiden rajat liukuvia tai neuvottelunvaraisia, kuten ruoan ja jätteen välisen rajanvedon yhteydessä (Koskinen ym. 2018; Mattila ym. 2019). Kestävyyden näkökulmasta materiaalitajun määritelmän sisältämä elinkaariajattelu ja materiaalivirtojen huomioiminen johdattelevat tarkastelemaan materiaalien alkuperää ja tuotantoreittejä tai vaikkapa materiaalien kulutuksesta syntyvää kokonaishiilijalanjälkeä.

Materiaalitajun käsitteen avulla voimme rakentaa ymmärrystä siitä, miten ihmiset kuluttajina luovasti oppivat materiaaleista ( $\mathrm{mm}$. niiden ominaisuudet, käyttökokemukset) ja muuttavat tapojaan olla vuorovaikutuksessa materiaalien kanssa osana arkeaan. Pyrimme materiaalitajun määritelmän myötä tuomaan kestävän kulutuksen tutkimuksen ja resurssien käytön keskusteluun aiempaa vahvemmin myös ajatuksen materiaalien aktiivisista toimijuuksista sekä materiaalisuhteiden monenlaisista yhteenliitännöistä kuluttajan arjessa. Materiaalitajun määritelmä sisältää ajatuksen jatkuvasti muuttuvista käytännöistä ja oppivista kuluttajista, jotka pyrkivät refleksiivisesti ja aktiivisesti ratkaisemaan toiminnassaan esiin nousevia pulmia ja jännitteitä. Näemme materiaalitajun käsitteen soveltamisen mahdolliseksi monenlaisissa empiirisissä konteksteissa ja suhteessa moniin erilaisiin materiaaleihin, joita kuluttajat kohtaavat ja hyödyntävät arjessaan. 


\section{Pohdinta ja johtopäätökset}

Artikkelimme keskeisenä tavoitteena on ollut hahmotella uutta, monitieteistä materiaalitajun käsitettä. Materiaalitajun käsitteen pyrkimyksenä on kontribuoida teoreettiseen keskusteluun kestävän kulutustutkimuksen alueella. Oppimisen näkökulmaa hyödyntävä tutkimus on kestävän kulutustutkimuksen kentällä kuitenkin ollut tähän mennessä vähäistä. Tämän näkökulman kattavampi hyödyntäminen kestävyystutkimuksessa voisi tuoda arvokasta lisäymmärrystä kuluttamiseen liittyvän muutoksen mahdollistamiseen ja tukemiseen kohti kuluttajan kestävää arkea ja elämää. Peräänkuulutamme tutkimusta, jossa huomioidaan sekä kuluttajien tilannesidonnaiset kyvyt käyttää materiaalisia resursseja kestävillä tavoilla että eri materiaalien aktiivinen osallistuminen näihin prosesseihin osana kestävyysmuutosta.

Kuten tässä artikkelissa hahmottelemamme materiaalitajun määritelmä sekä esiin nostamamme empiiriset esimerkit havainnollistavat, ilmenee materiaaleista oppiminen uusien tai uudistuvien tuotteiden kanssa elettäessä. Esimerkiksi kodin muuttuminen betonisesta puumateriaaliksi tai muovisen jugurttipurkin muuttuminen kartongiksi muovaa materiaalitajua tilanteisena kykynä olla kestävällä tavalla vuorovaikutuksessa ympäröivän todellisuuden kanssa. Olemme tuoneet esiin, että materiaalitajun kehittymistä voi tarkastella eri tasoilla (esimerkiksi kotitalouksissa, instituutiossa, osana ruokajärjestelmää tai globaalin kulutuskulttuurin näkökulmasta). Näin käsite voi tuoda uuden lähestymistavan siihen, miten voidaan rakentaa kestävämpiä materiasuhteita ja keinoja hyvään elämään antroposeenin aikakaudella (Evans 2019).

Artikkelimme tuottaa uutta tietoa erityisesti kestävän kulutustutkimuksen kentälle. Materiaalitajun määritelmämme huomioi materiaalisuuden aiempaa moniulotteisemmin (Lehtonen 2008; Jacobsen \& Hansen 2019), yhdistäen pragmatismia ja uusmaterialismia. Tähänastinen kestävän kuluttamisen tutkimus on keskittynyt pääasiassa inhimilliseen toimijuuteen kestävyysmuutoksen aikaansaamiseksi. Materiaalitajun käsite ottaa askeleen eteenpäin tästä ihmiskeskeisestä maailmankuvasta ja määrittelee kestävän kulutuksen vastuullisuudeksi, jonka toteutuminen ei lepää ainoastaan yksittäisten kuluttajien harteilla (ts. ei ole riippuvainen ainoastaan inhimillisestä toimijuudesta), vaan joka pitää sisällään myös situationaalisen ja monitahoisen vuorovaikutuksen materiaalien kanssa sekä materiaaleihin paikantuvan toimijuuden. Materiaalitajun määritelmä pyrkii ohjaamaan keskustelua kestävän kulutuksen ja materiaalisuhteen osalta elämän perusedellytysten mukaisiin materiaalisiin reunaehtoihin. Samalla se kuitenkin mahdollistaa myös modernin elämän materiaalisuuksien ilmenemismuotojen tarkastelun lukuisten erilaisten kestävyyteen tähtäävien sovellusten kautta. Tällaisia sovelluksia ovat esimerkiksi esittämämme ajatukset ruoan eloisuudesta ruokahävikin vähentämispyrkimyksissä (materiaalisuhteet osana kestävää ruokajärjestelmämurrosta) tai vaikkapa elämisestä uudenlaisten rakennusmateriaalien kanssa (materiaalisuhteet osana kestävää asumista).

Materiaalitajun käsite avaa mahdollisuuden tarkastella erilaisia materiaaleja kuluttajan arjessa monimuotoisemmin kuin pelkästään kuluttamisen välineinä, (staattisina) esinesuhteina tai toimintaympäristönä. Se ei ainoastaan auta huomioimaan kuluttajia tilanteisesti ja responsiivisesti uutta oppivina sekä kestäviä materiaalisuhteita rakentavina toimijoina: Se pyrkii myös edistämään ymmärrystä siitä, että kestäviinkin materiaalisuhteisiin sitoutunut toimijuus on aina jakaantunutta sekä enemmän tai vähemmän jatkuvaa (haurasta ja epävakaata) tekemistä ja ponnisteluita. Materiaalitajun käsitettä voidaan soveltaa kestävän kulutuksen tutkimukseen materiaalien elinkaaren eri vaiheissa $(\mathrm{mm}$. materiaalien hankinta, käyttö ja kierrätys). Oppimisteoreettista näkökulmaa hyödyntäen voitaisiin tarkastelua edelleen laajentaa materiaalien käytöstä muihinkin kestävän kulutuksen alueisiin, kuten taloudellisten (esim. rahallisten) resurssien käyttöön.

Materiaalitajun käsite on uusi avaus, minkä vuoksi sen teoreettista ja empiiristä kehittämistä on tärkeä jatkaa tulevissa tutkimuksissa. Seuraavissa vaiheissa tulisi esimerkiksi testata määritelmän sovellettavuutta suhteessa empiirisen aineiston keräämiseen ja 
analyysiin. Kiinnostavia jatkotutkimuksen aiheita osana materiaalitajun määrittelyä olisivat myös materiaalisten artefaktien sekundääriset ja tertiääriset olomuodot (ks. mm. Wartofsky 1979) ja digitaalinen materiaalisuus (ks. mm. Pink ym. 2016), kuten tietokoneen pikselit näytöllä tai erilaiset kategorisoinnit ja taksonomiat (esim. työohje, käsitekartta) sekä materiaalitajun moninaiset eettiset ja moraaliset ilmenemistavat, jotka tässä artikkelissa on jätetty tarkastelun ulkopuolelle. Pragmatismin ja uusmaterialismin kautta materiaalitajun käsite kohdentaa huomion sosiomateriaalisiin kohtaamisiin osana arkisia toimintaprosesseja, materiaalien kanssa jaetun toimijuuden merkityksiin osana muutosta kohti kestävämpää kuluttamista sekä materiaalisten ulottuvuuksien kietoutuneisuuden hahmottumiseen esimerkiksi kotitalouksien materiaalivirtoina. Tekemällä tietoisen eronteon yksilön kognitioon kohdistuvista tarkasteluista jää materiaalitajun käsitteessä väistämättä vähemmälle huomiolle esimerkiksi sellaiset refleksiivisen oppimisen muodot, jotka eivät suoraan ole havaittavissa muutoksena toiminnassa (ks. Elkjaer 2008). Oppimisen moninaisuuden haltuun ottamisen lisäksi tulevissa tutkimuksissa onkin tärkeää jatkaa pohdintaa myös siitä, millaisin erilaisin tavoin siirtymää rutinoituneista ja ei-kestävistä toimintatavoista kohti entistä kestävämpiä kulutuskäytäntöjä voitaisiin tukea.

\section{Kiitokset}

Kiitämme anonyymeja arvioitsijoita huolella laadituista kommenteista sekä Jaakko Autiota ja Kaisa Torkkelia arvokkaista huomioista käsikirjoituksen viimeistelyvaiheessa.

\section{Lähteet}

Akenji, L. (2019) Avoiding Consumer Scapegoatism: Towards a Political Economy of Sustainable Living. Dissertation Thesis. Department of Economics and Management. University of Helsinki, Helsinki. http://urn.fi/ URN:ISBN:978-951-51-5354-8

Appadurai, A. (2008 [1986]) Introduction. Teoksessa Appadurai, A. (toim.) The Social Life of Things: Commodities in Cultural Perspective, 3-63. Cambridge University Press, Cambridge.

Autio, M. (2019) Resurssien käytön renessanssi - kohti 1.5-asteista elämäntyyliä. Tieteessä tapabtuu 37 (2), 46-49. https://journal.fi/tt/article/view/79945

Barad, K. (2007) Meeting the universe halfway: Quantum physics and the entanglement of matter and meaning. Duke University Press, Durham \& London.

Bennett, J. (2007) Edible matter. New Left Review (45) 133-145. http://jhir.library.jhu.edu/handle/1774.2/32812

Bennett, J. (2010) Vibrant matter: A political ecology of things. Duke University Press, London.

Borgerson, J. L. (2013) The flickering consumer: New materialities and consumer research. Research in consumer behavior 15(1) 125-44. https:/ / doi.org/10.1108/S0885-2111(2013)0000015009

Dever, M. (2014) Photographs and manuscripts: working in the archive. Archives and Manuscripts 42(3) 282-294. https://doi.org/10.1080/01576895.2014.956322

Dewey, J. (1916) Democracy and Education. Free Press, New York.

Dewey, J. (1933 [1960]) How we think. A restatement of the relation of reflective thinking to the educative process. D. C. Heath and Company.

Dewey, J. (1938) Experience and Education. Macmillan Publishing, New York.

Dewey, J. (1958) Experience and Nature. Dover Publications Inc., New York.

Elkjaer, E. (2008) Pragmatism - a learning theory for the future. Teoksessa lleris K. (toim.) Contemporary theories of learning: Learning theorists ... Teoksessa their own words, 74-89. Routledge, London.

Evans, D. M. (2018) Rethinking material cultures of sustainability: commodity consumption, cultural biographies and following the thing. Transactions of the Institute of British Geographers 43(1) 110-121. https:// doi.org/10.1111/tran.12206

Evans, D. M. (2019) What is consumption, where has it been going, and does it still matter? The Sociological Review 67(3) 499-517. https://doi.org/10.1177/0038026118764028

Ferreira, M. C., \& Scaraboto, D. (2016) "My plastic dreams": Towards an extended understanding of materiality and the shaping of consumer identities. Journal of Business Research 69(1) 191-207. https://doi. org/10.1016/j.jbusres.2015.07.032

Fuentes, C. \& Sörum, N. (2019) Agencing ethical consumers: smartphone apps and the socio-material reconfiguration of everyday life. Consumption Markets \& Culture 22(2) 131-156. https://doi.org/10.1080 


\section{/10253866.2018.1456428}

Grosz, E. (2005) Time Travels: Feminism, Nature, Power. Allen \& Unwin, Sydney.

Groth, C (2017) Making Sense through Hands: Design and Craft Practice Analysed as Embodied Cognition. School of Arts, Design and Architecture, Aalto University. Teoksessa Libris, Finland. http://urn.fi/ URN:ISBN:978-952-60-7130-5

Haas, W., Krausmann, F., Wiedenhofer, D. \& Heinz, M. (2015) How circular is the global economy? An assessment of material flows, waste production, and recycling in the European Union and the world in 2005. Journal of Industrial Ecology 19(5) 765-777. https://doi.org/10.1111/jiec.12244

Hiller, A. \& Woodall, T. (2019) Everything Flows: A Pragmatist Perspective of Trade-Offs and Value in Ethical Consumption. Journal of Business Ethics 157(4) 893-912. https://doi.org/10.1007/s10551-018-3956-5

Humbert, S., Rossi, V., Margni, M. Jolliet, O. \& Loerincik, Y. (2009) Life cycle assessment of two baby food packaging alternatives: glass jars vs. plastic pots, International Journal of Life Cycle Assessment 14 95-106. https://doi-org.libproxy.helsinki.fi/10.1007/s11367-008-0052-6

Hoikkala, T, Hakkarainen, P \& Laine, S. (2005) Beyond health literacy. Youth Cultures, Prevention and Policy. Finnish Youth Research Network and Finnish Youth Research Society, Publications 52, Helsinki.

Ingold, T. (2012) Toward an ecology of materials. Annual Review of Anthropology 41 427-442. https://doi. org/10.1146/annurev-anthro-081309-145920

Jack, T. (2013) Nobody was dirty: Intervening in inconspicuous consumption of laundry routines. Journal of Consumer Culture 13(3) 406-421. https://doi.org/10.1177/1469540513485272

Jacobsen, M. H. \& Hansen, A. R. (2019) (Re)introducing embodied practical understanding to the sociology of sustainable consumption. Journal of Consumer Culture 1-17. https://doi.org/10.1177/1469540519846213

Janhonen, K., Torkkeli, K., \& Mäkelä, J. (2018) Informal learning and food sense in home cooking. Appetite 130 (1) 190-198. https://doi.org/10.1016/j.appet.2018.08.019

Jayanti, R. K. \& Singh, J. (2010) Pragmatic Learning Theory: An Inquiry Action Framework for Distributed Consumer Learning in Online Communities. Journal of Consumer Research 36(6) 1058-1081. https://www. jstor.org/stable/10.1086/648689

Kauppinen, E. (2018) Moniääninen ruokaympäristö - ruokakasvatuksen mabdollisuudet nuorisotaloilla. Väitöskirja (Monografia), Helsingin yliopisto. Yliopistopaino Unigrafia, Helsinki. http://urn.fi/ URN:ISBN:978-951-51-4591-8

Kaljonen, M., Peltola, T., Salo, M. \& Furman, E. (2019) Attentive, speculative experimental research for sustainability transitions: An exploration in sustainable eating. Journal of Cleaner Production 206(1) 365-373. https://doi.org/10.1016/j.jclepro.2018.09.206

Kaljonen, M., Peltola, T., Kettunen, M., Salo, M. \& Furman, E. (2018) Kasvisruokaa kouluun - kokeileva tutkimus ruokavaliomurroksen tukena. Alue ja Ympäristö 47(2) 32-47. https://doi.org/10.30663/ay.75114

Ketelsen, M. Janssen, M. \& Hamm, U. (2020) Consumers' response to environmentally-friendly food packaging - A systematic review. Journal of Cleaner Production 2541-22. https://doi.org/10.1016/j.jclepro.2020.120123

Kimura, A. (2011) Food education as food literacy: Privatized and gendered food knowledge in contemporary Japan. Agriculture and Human Values 28 465-482. https://doi.org/10.1007/s10460-010-9286-6

Kinnunen, V. (2017) Tavarat tiellä: sosiologinen tutkimus tavarasubteista muutossa. Akateeminen väitöskirja. Lapin yliopisto, Rovaniemi. http:/ / urn.fi/URN:ISBN:978-952-337-033-3

Kinnunen, V. (2018) Voiko jätettä rakastaa? Ilmiö: sosiologinen media kaikille. <https://ilmiomedia.fi/artikkelit/ voiko-jatetta-rakastaa>. 03.12.2020.

Kopytoff, I. (2008 [1986]) The cultural biography of things: commodification as a process. Teoksessa Appadurai, A. (toim.) The Social Life of Things: Commodities in Cultural Perspective, 64-91. Cambridge University Press, Cambridge.

Korsmeyer, C. \& Sutton, D. (2011) The Sensory Experience of Food. Food, Culture and Society 14(4) 461-475. https://doi.org/10.2752/175174411X13046092851316

Koskinen, O., Mattila, M., Närvänen, E., \& Mesiranta, N. (2018) Hoiva ruokahävikin vähentämisen arkisissa käytännöissä. Alue ja Ympäristö 47(2) 17-31. https://doi.org/10.30663/ay.72986

Kouhia, A. \& Janhonen, K. (2019) Knitting noodles: creating a playworld for craft through unconventional material experimentation. International Journal of Play 8(3) 289-307. https://doi.org/10.1080/21594937 .2019 .1684156

Kortesalmi, M. \& Autio, M. (2019) Talous- ja kuluttajakasvatus talousosaamisen mahdollistajana. Kansantaloudellinen Aikakauskirja 115(4) 588-603. https://www.taloustieteellinenyhdistys.fi/wp-content/ uploads/2019/11/KAK_4_2019_WEB-10-25.pdf

Kuipers, J. M. (2004). Scrapbooks: Intrinsic value and material culture. Journal of Archival Organization 2(3) 83-91. https://doi.org/10.1300/J201v02n03_07

Kyrk, H. (1923) A Theory of Consumption. Sir Isaac Pitman \& Sons Ltd, London.

Law,J. \& Singleton, V. (2005) Objectlessons. Organization 12(3) 331-355. https://doi.org/10.1177/1350508405051270

Law, J. \& Lien, M. E. (2013) Slippery: Field notes in empirical ontology. Social Studies of Science 43(3) 
363-378. https://doi.org/10.1177/0306312712456947

Lee, M. SW, Dewhirst, T. \& Cherrier, H. (2018) Introduction to the Special Section: The Domain and Intersection of Anticonsumption, Marketing, and Public Policy. Journal of Public Policy \& Marketing 37(2) 189-194. https://doi.org/10.1177/0743915618811852

Lehmann, S. (2013) Low carbon construction systems using prefabricated engineered solid wood panels for urban infill to significantly reduce greenhouse gas emissions. Sustainable Cities and Society 6 57-67. https:// doi.org/10.1016/j.scs.2012.08.004

Lehtonen, T-K. (2008) Aineellinen yhteisö. Tutkijaliitto, Helsinki.

Lehtonen, T.-K. (2015) Aineellinen yhteisö. 2. korjattu painos. Tutkijaliitto, Helsinki.

Lindh, H., Olsson, A. \& Williams, H. (2016) Consumer Perceptions of Food Packaging: Contributing to or Counteracting Environmentally Sustainable Development? Packaging Technology and Science 29 3-23. https:// doi.org/10.1002/pts.2184

Lim, W. M. (2017) Inside the sustainable consumption theoretical toolbox: Critical concepts for sustainability, consumption and marketing. Journal of Business Research 78 69-80. https://doi.org/10.1016/j. jbusres.2017.05.001

Lorek, S. (2009) Debunking Weak Sustainable Consumption - Towards Strong Sustainable Consumption Governance. Dissertation Thesis. Department of Economics and Management. University of Helsinki, Helsinki. http://urn.fi/URN:ISBN:978-952-10-5897-4

Matschoss, K., Kajoskoski, T., Laakso, S., Apajalahti, E. L., Heiskanen, E. \& Luomaniemi, V. (2019) Kokeilemalla kestäviin energiakäytäntöihin - yksin vai yhdessä? Kulutustutkimus.Nyt 13(2) 6-29. https:// journal.fi/kulutustutkimus/article/view/84702

Mattila, M., Mesiranta, N., Närvänen, E., Koskinen, O. \& Sutinen, U. M. (2019) Dances with potential food waste: Organising temporality in food waste reduction practices. Time \& Society 28(4) 1619-1644. https:// doi.org/10.1177/0961463X18784123

Meissner, M. (2019) Against accumulation: Lifestyle minimalism, de-growth and the present post-ecological condition. Journal of Cultural Economy 12(3) 185-200. https://doi.org/10.1080/17530350.2019.1570962

Miller, D. (2005) A Theory of Shopping. Polity Press, Cambridge.

Mol, A. (2002) The body multiple: ontology in medical practice. Duke University Press, Durham, London.

Mol, A. (2008) The logic of care. Health and the problem of patient choice. Routledge, London, New York.

Mäkelä, J. \& Niva, M. (2015) Citizens and sustainable culinary cultures. Teoksessa Palovirta, A. \& Järvelä, M. (toim.) Climate change adaptation and food supply chain management, 172-182. Routledge (Routledge Advances in Climate Change Research), Abingdon.

Northey, S. A., Mudd, G. M. \& Werner, T. T. (2018) Unresolved complexity in assessments of mineral resource depletion and availability. Natural Resources Research 27(2) 241-255. https://doi.org/10.1007/ s11053-017-9352-5

Närvänen, E., Mesiranta, N., Sutinen, U. M. \& Mattila, M. (2018) Creativity, aesthetics and ethics of food waste in social media campaigns. Journal of Cleaner Production 195 102-110. https://doi.org/10.1016/j. jclepro.2018.05.202

Ojajärvi, A. (2015) Terve sotilas! Etnografinen tutkimus varusmiesten terveystajusta sosiaalisena ilmiönä. Akateeminen väitöskirja. Nuorisotutkimusverkosto/Nuorisotutkimusseura. Verkkojulkaisuja 99, 2016, Sarja: Tiede. Helsingin yliopisto, Helsinki. http://urn.fi/URN:ISBN:978-952-5994-80-3

Phipps, M. \& Ozanne, J. L. (2017) Routines disrupted: Reestablishing security through practice alignment. Journal of Consumer Research 44(2) 361-380. https://doi.org/10.1093/jcr/ucx040

Pink, S., Ardèvol, E., \& Lanzeni, D. (2016) Digital materialities: Design and anthropology. London: Bloomsbury.

Prior, T., Giurco, D., Mudd, G., Mason, L. \& Behrisch, J. (2012) Resource depletion, peak minerals and the implications for sustainable resource management. Global environmental change 22(3) 577-587. https://doi. org/10.1016/j.gloenvcha.2011.08.009

Puig de la Bellacasa, M. (2017) Matters of care: speculative ethics in more than human worlds. University of Minnesota Press, Minneapolis \& London.

Pulkki, J. (2017) Kilpailun kasvatukesellisista ongelmista: Hyveitä 2000-luvulle. Akateeminen väitöskirja, Tampereen yliopisto. http://urn.fi/URN:ISBN:978-952-03-0592-5

Pulkki, J., Pulkki, J. \& Vadén, T. (2019) Ekoterveyskasvatuksen luonnos. Alue ja Ympäristö 48(2) 69-82. https:// doi.org/10.30663/ay.83089

Puuronen, A. (2006) Mitaä on terveys - tietoa, taitoa vai tajua? Teoksessa A. Puuronen, (toim.) (2006) Terveystaju. Nuoret, politiikeka ja käytäntö (ss. 5-20). Nuorisotutkimusseura ry: Nuorisotutkimusverkosto/ Nuorisotutkimusseura, julkaisuja 63.

Rekrut, A. (2006) Material literacy: reading records as material culture. Archivaria 60 11-37. https:/ / archivaria. $\mathrm{ca} /$ index.php/archivaria/article/view/12513

Røpke, I. (2009) Theories of practice - New inspiration for ecological economic studies. Ecological Economics 68 2490-2497. https://doi.org/10.1016/j.ecolecon.2009.05.015 
Sachs, W. (Ed.) (2017) The development dictionary: a guide to knowledge as power. $3^{\text {rd }}$ ed. Zed, London.

Sahakian, M. \& Wilhite, H. (2014) Making practice theory practicable: Towards more sustainable forms of consumption. Journal of Consumer Culture 14(1) 25-44. https://doi.org/10.1177/1469540513505607

Salminen, A. \& Vadén, T. (2013) Energia ja kokemus. Niin ja näin, Tampere. https://netn.fi/sites/www.netn. fi/files/syn_publication/files/netn-salminenvaden-energiajakokemus.pdf

Salminen, A. \& Vadén, T. (2018) Elo ja energia. Niin ja näin, Tampere.

Salo, M. \& Nissinen, A. (2017) Consumption choices to decrease personal carbon footprints of Finns. Reports of the Finnish Environment Institute 30. Finnish Environment Institute (SYKE), Helsinki.

Scaraboto, D., Ferreira, M. C. \& Chung, E. (2016) Materials matter: An exploration of the curatorial practices of consumers as collectors. Teoksessa Özçağlar-Toulouse, N., Rinallo, D \& Belk, R. W (toim.) Consumer Culture Theory, Research in consumer behavior 18 219-243. Emerald Group Publishing Limited, Bingley.

Scott, K., Martin, D. M. \& Schouten, J. W. (2014) Marketing and the new materialism. Journal of Macromarketing 34(3) 282-290. https://doi.org/10.1177/0276146714532471

Selby, D. \& Kagawa, F. (2018) Teetering on the brink: subversive and restorative learning in times of climate turmoil and disaster. Journal of Transformative Education 16(4) 302-322. https://doi.org/10.1177/1541344618782441

Shove, E. (2010) Beyond the ABC: climate change policy and theories of social change. Environment and Planning A 42(6) 1273-1285. https://doi.org/10.1068/a42282

Shove, E., \& Warde, A. (2002) Inconspicuous consumption: The sociology of lifestyles, consumption and the environment. Teoksessa Dunlap, R. E., Buttel, F. H., Dickens, P., Gijswijt, A. (toim.), Sociological theory and the environment: Classical foundations, contemporary insights, 230-251. Rowman and Littlefield, London.

Shove, E., Pantzar, M. \& Watson, M. (2012) The dynamics of social practice: Everyday life and how it changes. SAGE Publications Ltd, London.

Silcock, D. (2015) Marketing Pragmatism: a Constructive Review of Pragmatic Philosophy and Implications For Consumer Research. Teoksessa Diehl, K. \& Yoon, C. (toim.), NA - Advances in Consumer Research Volume 43, 212-217. Association for Consumer Research, Duluth, MN.

Solanki, S. (2018). Why Materials Matter: Responsible Design for a Better Future. Prestel, Munich.

Solanki, S. (2019) Material Literacy: Why we need to rethink language to survive the climate crisis. <https:// www.itsnicethat.com/features/response-and-responsibility-seetal-solanki-material-literacy-productdesign-260619>. 20.10.2020.

Solanki, S. (2020) We are not materialistic enough. Fusion Journal 18 4-8. <https://search.informit.com.au/ documentSummary; $\mathrm{dn}=275954322960394 ;$ res=IELHSS $>$. 03.12.2020.

Southerton, D., Warde, A. \& Hand, M. (2004) The limited autonomy of the consumer: implications for sustainable consumption. Teoksessa Southerton, D. Chappells, H. \& Van Vliet, B. (Eds.) Sustainable consumption: The implications of changing infrastructures of provision, 32-48. Edward Elgar, Manchester.

Sutton, D. (2010) Food and the senses. Annual Review of Anthropology 39 209-223. https://doi.org/10.1146/ annurev.anthro.012809.104957

Syrjälä, H., Jaskari, M. M., \& Leipämaa-Leskinen, H. (2016) Object agency of a living/non-living animal entity: the case of horse/horsemeat. Consumer Culture Theory (Research in Consumer Behavior) 18 65-91. Emerald Group Publishing Limited. https://doi.org/10.1108/S0885-211120160000018005

Tanhuanpää, A. (2017) Huoli kuvista: Merkitys, mieli, materiaalisuus. Jyväskylä Studies in the Humanities 315. University of Jyväskylä, Jyväskylä. http://urn.fi/URN:ISBN:978-951-39-7069-7

Tarrant, S. P., \& Thiele, L. P. (2016) Practice makes pedagogy-John Dewey and skills-based sustainability education. International Journal of Sustainability in Higher Education 17(1) 54-67. https://doi.org/10.1108/ IJSHE-09-2014-0127

The Circularity Gap Report (2019) Circularity Gap Reporting Initiative - Home. <https://www.circularity-gap. world>. 03.12.2020.

Thomas, G. O., Sautkina, E., Poortinga, W., Wolstenholme, E., \& Whitmarsh, L. (2019) The english plastic bag charge changed behavior and increased support for other charges to reduce plastic waste. Frontiers in psychology 10 266. https://doi.org/10.3389/fpsyg.2019.00266

Thomas, C. \& Sharp, V. (2013) Understanding the normalisation of recycling behavior and its implications for other pro-environmental behaviours: A review of social norms and recycling. Resources, Conservation and Recycling 79 11-20. https://doi.org/10.1016/j.resconrec.2013.04.010

Torkkeli, K., Niva, M. \& Mäkelä, J. (2018) Elements of practice in the analysis of auto-ethnographical cooking videos. Journal of Consumer Culture 20(4) 543-562. https://doi.org/10.1177/1469540518764248

Torkkeli, K., Janhonen, K. \& Mäkelä, J. (2020) Engagements in Situationally Appropriate Home Cooking, Food, Culture and Society, Accepted/Teoksessa press.

Truman, E., Lane, D. \& Elliott, C. (2017) Defining food literacy: A scoping review. Appetite 116 365-371. https://doi.org/10.1016/j.appet.2017.05.007

UNESCO Education Sector Position Paper (2003) The Plurality of Literacy and its Implications for Policies and Programmes. http://unesdoc.unesco.org/images/0013/001362/136246e.pdf 
Vaitkeviciute, R., Ball, L. \& Harris, N. (2015) The relationship between food literacy and dietary intake in adolescents - A systematic review. Public Health Nutrition 18 649-558. https://doi.org/10.1017/ S1368980014000962

Van Poeck, K., Östman, L. \& Block, T. (2020) Opening up the black box of learning-by-doing in sustainability transitions. Environmental Innovation and Societal Transitions 34 298-310. https://doi.org/10.1016/j. eist.2018.12.006

Viholainen, N., Kylkilahti, E., Autio, M. \& Toppinen, A. (2020) A home made of wood: Consumer experiences of wooden building materials. International Journal of Consumer Studies 44(6) 542-551. https:// doi.org/10.1111/ijcs.12586

Warde, A. (2015). The sociology of consumption: Its recent development. Annual Review of Sociology 41 117-134. https://www.annualreviews.org/doi/abs/10.1146/annurev-soc-071913-043208

Wartofsky, Marx W. (1979). Models: Representation and scientific understanding. Reidel, Dordrecht.

WCED (1987) Our Common Future (the Brundtland Report). Oxford: Oxford University Press. 